\title{
PENGEMBANGAN BUKU AJAR PENDIDIKAN IPA KELAS IV SEMESTER I SD NO. 4 KALIUNTU DENGAN MODEL DICK AND CAREY
}

\author{
Putu Sukerni \\ Guru SD NO.4 Kaliuntu \\ Singaraja, Indonesia
}

e-mail: sukerni_bali@yahoo.com

\begin{abstract}
Abstrak
Tujuan penelitian adalah untuk mengetahui: (1) langkah-langkah pengembangan buku Pendidikan IPA Kelas IV Semester 1 dengan model Dick \& Carey dan (2) hasil uji coba bahan ajar metode penelitian pengembangan pendidikan. Model pengembangan yang digunakan adalah Dick \& Carey. Langkah- langkah pengembangan buku ajar ini meliputi: (1) mengidentifikasi tujuan pembelajaran, (2) melakukan analisis pembelajaran, (3) mengidentifikasi perilaku awal dan karakteristik pebelajar, (4) menulis tujuan pembelajaran khusus, (5) mengembangkan butir-butir tes acuan patokan, (6) mengembangkan strategi pembelajaran, (7) mengembangkan dan memilih materi pembelajaran, (8) mendesain dan melakukan evaluasi formatif, dan (9) merevisi pembelajaran. Instrumen yang digunakan adalah angket dan pedoman wawancara. Data dianalisis dengan teknik analisis deskriptif kualitatif dan analisis statistik deskriptif. Hasil uji kelompok kecil menunjukkan bahwa bahan ajar berada pada kualifikasi cukup baik. Ahli desain pembelajaran dan ahli media pembelajaran menilai bahan ajar berada pada kualifikasi baik.
\end{abstract}

Kata Kunci: buku ajar, pengembangan, model Dick \& Carey

\begin{abstract}
This research aimed at finding out: (1) the steps of developing Dick and Carey model based educational science textbook for the first semester grade four of SD No.4 Kaliuntu and (2) the result of testing the Dick and Carey model based educational science textbook. The steps of developing this textbook were (1) identifying the learning objective (2) doing learning analysis (3) identifying learners' initial behavior and characteristics (4) making special learning objective (5) developing test items (6) developing learning strategy (7) developing and choosing learning material (8) designing and doing formative assessment and (9) revising the textbook. The instruments were questionnaire and interview guidance. The data were analyses through descriptive qualitative and descriptive statistics. The result of expert judgment showed that the material was fair. The expert of learning design and media judged that this material was good. Research result in small group showed that the material was fair.
\end{abstract}

Keywords: development, Dick \& Carey model, textbook 


\section{PENDAHULUAN}

Gagne (1990) menyatakan bahwa penelitian pengembangan adalah suatu usaha mengembangkan suatu produk yang efektif digunakan sekolah. Pendidikan memegang peranan sangat penting dalam menciptakan sumber daya manusia (SDM) yang berkualitas. Sekolah sebagai lembaga pendidikan formal merupakan wadah peningkatan kualitas SDM. Manusia yang berkualitas menjadi tumpuan utama suatu bangsa untuk dapat bersaing dengan bangsabangsa lain di dunia. Sekolah Dasar merupakan jenjang pendidikan dasar yang mengelola pendidikan anak usia sekitar 7 sampai 11 tahun. Dalam pelaksanaan pembelajaran perlu dilandasi dengan sikap yang ilmiah yang termasuk sikap ilmiah utama dalam berproses sains ialah: Obyektif, subyektif,obyektifitas, teliti, terbuka, dan kritis. Buku yang digunakan adalah buku yang bersumber dari BSE terbitan departemen pendidikan nasional. Berdasarkan analisis kebutuhan para guru membutuhkan buku ajar yang sesuai dengan karakteristik dan kebutuhan siswa dalam belajar.

Permasalahan yang sering terjadi di sekolah yang berkaitan dengan proses belajar mengajar adalah: kajian materi setiap buku ajar bervariasi,materi yang terdapat dalam buku ajar tidak sesuai dengan karakteristik siswa. Kondisi ini yang memacu melakukan kegiatan pengadaan buku yang relevan dengan mata pelajaran dan sesuai dengan karakteristik dan kebutuhan siswa dan gambar-gambar pembelajaran yang sesuai dengan karakteristik dan kebutuhan siswa. Oleh karena itu, dipandang perlu untuk mengembangkan paket pembelajaran mata pelajaran IPA Kelas IV di SD.No.4 Kaliuntu.

Dalam penelitian pengembangan ini, produk pengembangan yang dihasilkan berupa satu paket pembelajaran mata pelajaran IPA kelas IV , terdiri kata kunci, peta epitomologi, petunjuk penggunaan bahan ajar, kerangka isi, kompetensi dasar, indikator, uraian materi dan sumber pendukung. Produk yang dihasilkan dalam pengembangan ini memiliki kekhasan atau keistimewaan tertentu. Misalnya, bahan ajar yang dihasilkan dalam pengembangan ini akan memberikan tantangan-tantangan bagi pebelajar untuk belajar (challenge), bukan sekadar menerima informasi (reception). Bahan ajar menuntun pebelajar agar aktif dalam pembelajaran melalui pemberian materi yang disertai dengan gambar yang sangat berkaitan dengan kehidupan siswa, tugas mandiri yang dapat dikerjakan secara individu atau kelompok setiap materi, ringkasan materi setiap bab dan tes akhir bab. Bahan ajar yang ada selama ini di SD tidak dilengkapi dengan tugas mandiri. Sehingga dipandang perlu untuk membuat buku ajar. Kegiatan yang digunakan untuk mengembangkan bahan ajar ini adalah Model Dick \& Carey dan hanya dilakukan sampai evaluasi formatif. Pemilihan model ini didasari atas pertimbangan bahwa model ini dikembangkan secara sistematis dan berpijak pada landasan teoretis desain pembelajaran. Model ini disusun secara terprogram dengan urutan-urutan kegiatan yang sistematis dalam upaya pemecahan masalah belajar yang berkaitan dengan sumber belajar yang sesuai dengan kebutuhan dan karakteristik pebelajar. Model ini 
terdiri atas sembilan langkah, yaitu: (1) mengidentifikasi tujuan pembelajaran, (2) melakukan analisis pembelajaran, (3) mengidentifikasi perilaku awal dan karakteristik pebelajar, (4) menulis tujuan pembelajaran khusus, (5) mengembangkan butir-butir tes acuan patokan, (6) mengembangkan strategi pembelajaran, (7) mengembangkan dan memilih materi pembelajaran, (8) mendesain dan melakukan evaluasi formatif, dan (9) merevisi pembelajaran.

Buku ajar adalah bahan-bahan atau materi pembelajaran yang disusun secara sistematis yang digunakan guru dan siswa dalam proses pembelajaran (Pannen dan Purwanto, 2001). Buku ajar mempunyai struktur dan urutan yang sistematis, menjelaskan tujuan instruksional yang akan dicapai, memotivasi siswa untuk belajar, mengantisipasi kesukaran belajar siswa dalam bentuk penyediaan bimbingan bagi siswa untuk mempelajari buku tersebut, memberikan latihan yang banyak bagi siswa, menyediakan rangkuman, dan secara umum berorientasi kepada siswa secara individual (learner oriented).

Dalam pengembangan paket pembelajaran ini, prosedur pengembangan yang dilakukan terdiri atas beberapa tahap. Tahap-tahap pengembangan dipaparkan dalam uraian berikut ini.

1. Tahap I menentukan mata pelajaran yang akan dikembangkan. Mata pelajaran yang dikembangkan adalah mata pelajaran IPA SD kelas IV

2. Tahap II mengidentifikasi kompetensi dasar. Melakukan analisis pembelajaran, mengidentifikasi perilaku awal dan karakteristik pebelajar, menulis indikator, dan mengembangkan butir-butir tes acuan patokan.

3. Tahap III mengembangkan strategi pembelajaran dan mengembangkan dan/atau memilih materi pembelajaran. Dalam tahap ini disusun strategi pembelajaran untuk mencapai tujuan yang telah ditetapkan. Kegiatan ini meliputi aktivitas prapembelajaran, penyajian informasi dan umpan balik, pengetesan, dan kegiatan tindak lanjut.

4. Tahap IV penyusunan dan penulisan buku ajar, Buku ajar mempunyai komponen pembelajaran yang meliputi: (1) judul bab dan konsepkonsep kunci, (2) petunjuk, (3) kerangka isi, (4) kompetensi dasar, (5) indikator, (6) materi, (7) tugas dan latihan, (8) rangkuman, (10) tes akhir bab, dan (11) sumber pendukung. Panduan siswa berisi petunjuk bagi siswa dalam memanfaatkan buku ajar dalam pembelajaran.

5. Tahap $\mathrm{V}$ mendesain dan melakukan evaluasi formatif dan merevisi produk pengembangan, Evaluasi formatif meliputi uji ahli isi, uji ahli desain dan media pembelajaran, uji coba perorangan, uji coba kelompok kecil, dan uji coba lapangan. Datadata yang diperoleh dari masingmasing kegiatan uji coba tersebut dianalisis dan hasil analisis digunakan untuk merevisi produk pengembangan

Mengingat kedudukan bahan ajar untuk digunakan bersama-sama oleh guru dan siswa dalam pembelajaran, maka buku ajar 
dirancang secara sistematis dengan susunan setiap bab sebagai berikut:(1) Judul bab dan konsep-konsep kunci (2) Petunjuk Penggunaan Bahan Ajar, (3) Kerangka Isi,(4) Kompetensi Dasar, (5) Indikator, (6) Penyajian Materi setiap bab, (7) Tugas dan Latihan, (8) Rangkuman Materi, (9) Tes Akhir Bab, (10) Sumber Pendukung.

Cennamo \& Kalk (2005) dalam sebuah artikelnya menyoroti tentang desain pembelajaran sistem dan sistematik yang memiliki kelemahankelemahan, sehingga perlu diupayakan sebagai proses iteratif (non linear) yang merupakan model fungsional dalam praktik dunia nyata. Menyadari bahwa model Dick \& Carey adalah sebuah model rancangan pembelajaran yang bersifat sistemik dan linear, pengembang mencoba untuk menerapkan proses iteratif dalam buku ajar yang dikembangkan. Usaha ini diwujudkan dengan cara memberikan umpan balik dan tindak lanjut pada setiap siswa selesai mengerjakan tes akhir bab. Pemberian tes sambil jalan (embedded test) di sela-sela materi juga merupakan usaha untuk sedikit mengurangi sifat linear model Dick \& Carey. Dengan tes ini, siswa dapat merefleksi materi yang telah dibacanya.

Hackbarth (1996) mengatakan bahwa prosedur yang menggambarkan pendekatan sistematik dalam pengembangan pembelajaran dibagi ke dalam lima fase. Kelima fase tersebut adalah 1. mendiagnosa (diagnose), 2. merancang (design), 3. mendapatkan (procure), 4. memproduksi (produce), dan 5. menghaluskan (refine). Fase mendiagnosa meliputi dua langkah, yaitu memperhitungkan apa yang dibutuhkan oleh pebelajar untuk diketahui dan menilai apa yang telah pebelajar ketahui. Fase merancang terdiri atas kegiatan merancang tes peningkatan belajar, mengidentifikasi strategi pembelajaran yang efektif, memilih media yang sesuai, mengurutkan aktivitas belajar dalam program, merencanakan aktivitas pendahuluan, dan merencanakan aktivitas selanjutnya. Fase mendapatkan meliputi menjamin materi ada di tangan dan mendapatkan materi baru. Dalam fase memproduksi, kegiatan yang dilakukan adalah memodifikasi materi yang ada dan materi yang baru. Fase menghaluskan terdiri atas melakukan program tes skala kecil, mengevaluasi prosedur dan prestasi, memperbaiki sesuai dengan program, melakukan program tes kelas, evaluasi prosedur dan prestasi, dan merevisi dalam mengantisipasi sekolah masa depan. Dalam rancangan pembelajaran model Dick \& Carey, kelima fase di atas terlihat dengan jelas dalam langkah-langkah yang disusun oleh mereka.

\section{METODE PENELITIAN}

Model pengembangan yang digunakan dalam pengembangan paket pembelajaran IPA SD Kelas IV ini adalah Model Dick \& Carey (1990) yang merupakan salah satu model desain pembelajaran sistematik. Model ini terdiri atas sembilan langkah, yaitu: (1) mengidentifikasi tujuan pembelajaran, (2) melakukan analisis pembelajaran, (3) mengidentifikasi perilaku awal dan karakteristik pebelajar, (4) menulis tujuan pembelajaran khusus, (5) mengembangkan butir-butir tes acuan patokan, (6) mengembangkan strategi pembelajaran, (7) mengembangkan dan 
memilih materi pembelajaran, (8) mendesain dan melakukan evaluasi formatif, dan (9) merevisi pembelajaran.

Subyek coba produk hasil pengembangan ini adalah satu orang ahli isi mata pelajaran IPA SD. Ahli isi mata pelajaran dalam penelitian pengembangan ini adalah Putu Nanci Riastini, S.Pd., M.Pd. Beliau adalah seorang dosen IPA pada Universitas Pendidikan Ganesha. Siswa kelas IV di SD NO,4 kaliuntu. Semua siswa diberikan kesempatan untuk menilai buku ajar. Siswa menilai secara perorangan yang berjumlah 6 orang.

Data-data yang dikumpulkan melalui pelaksanaan evaluasi formatif dikelompokkan menjadi empat bagian, yaitu: (1) data evaluasi tahap pertama berupa data hasil uji ahli isi mata pelajaran, (2) data evaluasi tahap kedua berupa data hasil uji coba perorangan,data hasil uji coba kelompok kecil, dan data hasil uji lapangan berupa data hasil pretes dan postes siswa, data hasil review siswa, dan data hasil review dosen pembina mata pelajaran IPA SD. Seluruh data yang diperoleh dikelompokkan menurut sifatnya menjadi dua, yaitu data kualitatif dan data kuantitatif. Instrumen yang digunakan untuk mengumpulkan data dalam penelitian pengembangan ini adalah angket, pedoman wawancara, dan tes. Angket dan pedoman wawancara digunakan untuk mengumpulkan data hasil review dari ahli isi bidang studi, siswa saat uji coba perorangan dan kelompok kecil, siswa saat uji lapangan, dan dosen pembina mata pelajaran IPA SD saat uji lapangan. Tes digunakan untuk mengetahui hasil belajar siswa sebelum menggunakan paket pembelajaran (pretes) dan sesudah menggunakan paket pembelajaran (postes). Teknik analisis deskriptif kualitatif ini digunakan untuk mengolah data hasil review ahli isi mata pelajaran, siswa, dan dosen pembina mata pelajaran. Teknik analisis data ini dilakukan dengan mengelompokkan informasi-informasi dari data kualitatif yang berupa masukan, tanggapan, kritik, dan saran perbaikan yang terdapat pada angket dan hasil wawancara. Hasil analisis data ini kemudian digunakan untuk merevisi produk paket pembelajaran.

\section{HASIL DAN PEMBAHASAN}

Buku ajar yang telah selesai dilakukan uji coba buku ajar tersebut. Berikut ini diuraikan hasil uji coba produk pengembangan mulai uji coba ahli isi,ahli media sampai uji coba perorangan dengan subjek coba siswa kelas 4 yang berjumlah 6 orang.

\section{a. Uji Coba Ahli Isi}

Dalam uji coba ini ahli isi mata pelajaran yang dijadikan subjek coba adalah Dr. I Made Kirna, M.Si. Subjek coba dimohon untuk menilai produk pengembangan dari segi isi/materi mata pelajaran IPA kelas 4 semester I melalui angket tertutup dan terbuka. Hasil penilaian ahli isi mata pelajaran IPA kelas 4 semester I melalui angket tertutup disajikan pada Tabel 1. 
Tabel 1 Penilaian Ahli Isi

\begin{tabular}{|c|l|c|}
\hline No. & \multicolumn{1}{|c|}{ Kriteria } & Skor \\
\hline 1 & Ketepatan judul bab dengan isi materi dalam tiap bab & 4 \\
\hline 2 & Kejelasan petunjuk pada tiap bab & 3 \\
\hline 3 & Kejelasan kerangka isi & 4 \\
\hline 4 & Kesesuaian antara standar kompetensi dan tujuan pembelajaran & 4 \\
\hline 5 & Keoperasionalan tujuan pembelajaran & 4 \\
\hline 6 & Kesesuaian antara tujuan pembelajaran dan paparan materi & 4 \\
\hline 7 & Kejelasan uraian materi & 3 \\
\hline 8 & Kejelasan contoh-contoh yang diberikan & 3 \\
\hline 9 & Keseuaian antara gambar/ilustrasi dan materi & 4 \\
\hline 10 & $\begin{array}{l}\text { Kesesauian antara embedded tes di sela-sela uraian materi } \\
\text { dengan uraian materi }\end{array}$ & 3 \\
\hline 11 & Kejelasan tugas dan latihan yang diberi & 4 \\
\hline 12 & Kejelasan antara tugas dan latihan yang materi & 4 \\
\hline 13 & Ketepatan pemilihan isi rangkuman & 4 \\
\hline 14 & Kesesuaian antara tes akhir bab dengan tujuan pembelajaran & 3 \\
\hline 15 & $\begin{array}{l}\text { Ketepatan sumber pendukung yang didapat dijadikan acuan } \\
\text { mencari sumber bacaan yang relevan dengan materi. }\end{array}$ & 55 \\
\hline & \multicolumn{2}{c}{ Jumlah } \\
\hline
\end{tabular}

Berdasarkan data pada Tabel 1 maka dapat dihitung persentase penilaian oleh ahli isi $73,33 \%$

Pada angket yang terbuka terdapat beberapa masukan dari ahli mata pelajaran IPA: 1) Beberapa halaman di daftar isi tidak sesuai dengan di paparan isi, 2) Akan lebih baik apabila struktur bab dimulai dari $\mathrm{KD}$, indikator,konsep kunci dan epitom, deskripsi ringkas untuk penghantar ke isi kemudian paparan isi, 3) Ada beberapa penulisan kata depan tidak dipisah, 4)Warna gambar kurang menarik.

b. Uji Coba Ahli Desain Pembelajaran Subjek coba dalan uji coba ini adalah Dr I Made Tegeh, M.Pd. Hasil kuesioner tertutup disajikan dalam tabel berikut ini. 
Tabel 2 Penilaian Ahli Desain Pembelajaran

\begin{tabular}{|c|l|c|}
\hline No. & \multicolumn{1}{|c|}{ Kriteria } & Skor \\
\hline 1 & Kualitas penjilidan & 4 \\
\hline 2 & Kemenarikan desain cover & 5 \\
\hline 3 & Ketepatan lay out pengetikan & 5 \\
\hline 4 & $\begin{array}{l}\text { Kekonsistenan penggunaan spasi, judul, subjudul, dan } \\
\text { pengetikan materi }\end{array}$ & 4 \\
\hline 5 & Kejelasan tulisan/pengetikan & 5 \\
\hline 6 & Kelengkapan komponen-komponen pada setiap bab buku ajar & 4 \\
\hline 7 & Ketepatan cara penyajian materi & 4 \\
\hline & \multicolumn{1}{|c|}{ Jumlah } & 31 \\
\hline
\end{tabular}

Berdasarkan data pada Tabel 2 maka dapat dihitung persentase penilaian oleh ahli desain pembelajaran $88,57 \%$.

Pada angket terbuka ahli desain pembelajaran memberikan beberapa masukan sebagai berikut: 1) Buku yang baik, ke depan dikembangkan lagi, misalnya, model-model penelitian pengembangan, multimedia, dan lain- lain, 2) Gambar yang ada pada setiap bab diisi penomoran di bawah gambar.

c. Uji Coba Ahli Media Pembelajaran

Penilaian unsur media pembelajaran dalam buku ajar dilakukan oleh ahli media pembelajaran. Subjek coba ahli media pembelajaran adalah Dr. I Komang Sudarma, M.Pd. Hasil kuesioner tertutup disajikan dalam tabel berikut ini.

Tabel 3 Penilaian Ahli Desain Pembelajaran

\begin{tabular}{|c|l|c|}
\hline No. & \multicolumn{1}{|c|}{ Kriteria } & Skor \\
\hline 1 & Ketepatan ilustrasi yang digunakan dalam cover & 4 \\
\hline 2 & Kesesuaian antara materi dan media yang digunakan & 4 \\
\hline 3 & Kualitas gambar yang digunakan & 3 \\
\hline 4 & Ketepatan ukuran gambar & 4 \\
\hline 5 & Ketepatan penempatan gambar & 4 \\
\hline 6 & Kualitas teks & 4 \\
\hline 7 & Kualitas tabel dan grafik Jumlah & 4 \\
\hline & \multicolumn{1}{|c|}{ Ju } \\
\hline
\end{tabular}

Berdasarkan data pada Tabel 3, maka dapat dihitung persentase penilaian oleh ahli media pembelajaran $77,14 \%$

Pada angket terbuka ahli media pembelajaran memberikan masukan yaitu Usahakan komposisi peta epitome (dari sisi warna dan posisi struktur peta konsep) harus sama.

\section{d. Uji Coba Perorangan}

Dalam uji coba ini siswa yang dijadikan subjek coba adalah siswa kelas 4 SD.No.4 Kaliuntu yang berjumlah enam orang. 
Pada angket yang terbuka terdapat beberapa masukan dari para siswa: Gambar yang berkaitan dengan lingkungan sekolah diperbanyak supaya menarik, Warna gambar kurang bagus, Tes akhir soalnya kurang menantang,Susunan kalimatnya kurang sistematis. e. Uji Coba Kelompok Kecil

Dalam uji coba ini siswa yang dijadikan subjek coba adalah siswa kelas 4 SD.No.4 Kaliuntu yang berjumlah tiga orang. Hasil penilaian siswa melalui angket tertutup disajikan pada Tabel berikut.

Tabel 4 Penilaian Uji Kelompok Kecil

\begin{tabular}{|c|c|c|c|c|}
\hline No. & Kriteria & \multicolumn{3}{|c|}{ Skor siswa } \\
\hline 1 & Bagaimanakah tampilan fisik buku ajar & 4 & 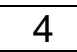 & \\
\hline 2 & $\begin{array}{l}\text { Apakah kerangka isi pada bagian awal bab membantu } \\
\text { Anda memahami isi bacaan }\end{array}$ & 4 & 3 & 4 \\
\hline 3 & $\begin{array}{l}\text { Bagaimanakah tingkat kejelasan petunjuk pada tiap } \\
\text { awal bab }\end{array}$ & 4 & 3 & 3 \\
\hline 4 & $\begin{array}{l}\text { Apakah ukuran dan jenis huruf yang digunakan dalam } \\
\text { buku ajar mudah dibaca }\end{array}$ & 5 & 5 & 4 \\
\hline 5 & Bagaimana kejelasan tujuan pembelajaran & 4 & 4 & 4 \\
\hline 6 & kejelasan paparan materi pada tiap bab & 4 & 4 & 3 \\
\hline 7 & $\begin{array}{l}\text { tingkat kesesuaian antara gambar dan } \\
\text { kku ajar }\end{array}$ & 4 & 4 & 3 \\
\hline 8 & $\begin{array}{l}\text { ontoh yang diberikan } \\
\text { i }\end{array}$ & 4 & 4 & 3 \\
\hline 9 & $\begin{array}{l}\text { il jalan (embedded test) dalam uraian } \\
\text { t bagi anda dalam memahami materi }\end{array}$ & 4 & 3 & 4 \\
\hline 10 & Bagaim & 4 & 4 & 4 \\
\hline 11 & $\begin{array}{l}\text { embantu } \\
\text { eri }\end{array}$ & 4 & 4 & 3 \\
\hline 12 & $\begin{array}{l}\text { Bagaimanakah tingkat kejelasan rangkuman pada } \\
\text { bagian akhir bab }\end{array}$ & 4 & 4 & 4 \\
\hline 13 & $\begin{array}{l}\text { Apakah tes akhir bab, kunci jawaban, umpan balik dan } \\
\text { tindak lanjut pada bagian akhir buku ajar membantu } \\
\text { Anda untuk mengetahui tingkat penguasaan materi tiap } \\
\text { bab }\end{array}$ & 4 & 3 & 4 \\
\hline 14 & $\begin{array}{l}\text { Bagaimana urutan penyajian materi pada tiap bab buku } \\
\text { ajar ini }\end{array}$ & 4 & 4 & 3 \\
\hline & & 5 & 53 & 50 \\
\hline & 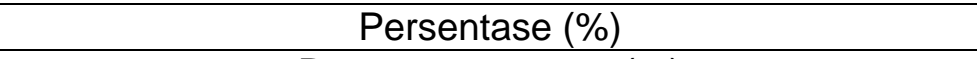 & 81 & 76 & 71 \\
\hline
\end{tabular}




\section{PEMBAHASAN}

Pembahasan difokuskan pada penyajian dan analisis data serta revisi yang dilakukan terhadap produk pengembangan. Hasil penilaian ahli isi berdasarkan angket tertutup menunjukkan bahwa persentase yang diperoleh buku ajar adalah 73,33\%. Persentase tersebut bila dikonversikan ke dalam tabel konversi tingkat pencapaian skala 4 (lihat Tabel 3.1 halaman 17) berada pada kualifikasi cukup. Hal ini berarti bahwa buku ajar perlu direvisi secukupnya.

Adapun revisi-revisi yang dilakukan terhadap buku ajar berdasarkan masukan ahli isi adalah sebagai berikut : Beberapa halaman di daftar isi tidak sesuai dengan di paparan isi, akan lebih baik apabila struktur bab dimulai dari $\mathrm{KD}$, indikator, konsep kunci dan epitom, deskripsi ringkas untuk penghantar ke isi kemudian paparan isi, ada beberapa penulisan kata depan tidak dipisah, warna gambar kurang menarik

\section{Hasil penilaian ahli desain}

pembelajaran terhadap produk pengembangan berdasarkan angket tertutup menunjukkan bahwa persentase perolehan buku ajar adalah $88,57 \%$. Bila dikonversikan ke dalam tabel konversi tingkat pencapaian skala 4, persentae ini berada pada kualifikasi baik. Hal ini berarti bahwa buku ajar perlu sedikit revisi. Satu hal yang disarankan oleh ahli desain pembelajaran adalah diperlukan pengisian nomor pada setiap gambar. Dengan demikian, revisi yang dilakukan adalah mengisi nomor pada setiap gambar yang ada pada buku ajar tersebut.

Dari hasil penilaian ahli media pembelajaran dengan analisis statistik deskriptif persentase buku ajar berada pada prosentase $77,14 \%$ dengan kualifikasi baik. Persentase ini bila dibandingkan dengan tabel konversi tingkat pencapaian skala 4 berada pada kualifikasi baik. Hal ini berarti bahwa buku ajar hanya memerlukan sedikit revisi.

Pada angket terbuka ahli media pembelajaran memberikan masukan. Berdasarkan masukan yang diberikan, maka dilakukan revisi terhadap buku ajar. Adapun revisi-revisi buku ajar berdasarkan masukan ahli media pembelajaran adalah usahakan komposisi peta epitome ( dari sisi warna dan posisi struktur peta konsep) harus sama.

Subjek uji coba perorangan adalah tiga orang siswa sedangkan uji coba kelompok kecil adalah 3 orang siswa kelas IV SD No.4 Kaliuntu dengan kemampuan rendah, sedang, dan tinggi. Berdasarkan hasil analisis statistik deskriptif persentase buku ajar berada pada prosentase $76,67 \%$ dengan kualifikasi cukup, sehingga buku ajar perlu direvisi secukupnya sesuai masukan yang diberikan melalui angket terbuka.

Revisi-revisi yang dilakukan berdasarkan masukan saat uji coba perorangan adalah sebagai berikut: Desain cover luar buku ajar dibuat lebih menarik dengan penambahan warna dan gambar yang relevan dengan isi buku ajar,perbaikan terhadap beberapa salah ketik yang terdapat dalam buku ajar,susunan kalimat kurang sistematis, warna gambar kurang menarik minat siswa. 


\section{SIMPULAN}

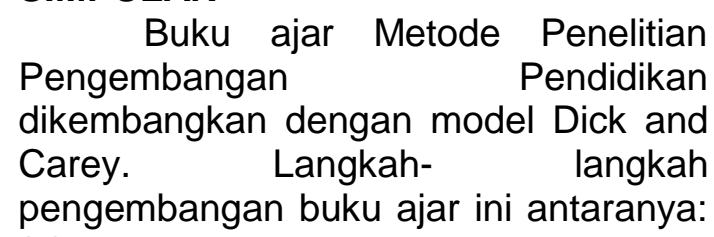
(1) mengidentifikasi tujuan pembelajaran, (2) melakukan analisis pembelajaran, (3) mengidentifikasi perilaku awal dan karakteristik pebelajar, (4) menulis tujuan pembelajaran khusus, (5) mengembangkan butir-butir tes acuan patokan, (6) mengembangkan strategi pembelajaran, (7) mengembangkan dan memilih materi pembelajaran, mendesain dan melakukan evaluasi formatif, dan (9) merevisi pembelajaran. Setelah prototype bahan ajar selesai dikembangkan, maka dilakukan uji-uji coba. Uji coba yang dilakukan adalah uji coba ahli yang mencakup ahli isi mata pelajaran IPA, ahli desain pembelajaran. Selanjutnya dilakukan uji coba perorangan yang melibatkan enam orang siswa dengan kemampuan yang berbeda (rendah, sedang, dan tinggi).

Hasil uji ahli isi mata pelajaran menunjukkan bahwa persentase perolehan buku ajar adalah $73,33 \%$. Persentase ini berada pada kualifikasi cukup baik, sehingga buku ajar perlu direvisi secukupnya. Ahli desain pembelajaran menilai buku ajar berada pada persentase $88,57 \%$. Persentase ini berada pada kualifikasi baik, yang berarti buku ajar hanya perlu sedikit revisi. Persentase yang diberikan oleh ahli media pembelajaran yakni $77,14 \%$. Hal ini berarti bahwa buku ajar berada pada kualifikasi baik dan perlu sedikit revisi. Pada saat uji coba perorangan yang melibatkan tiga orang siswa kelas 4 SD.No.4 Kaliuntu, hasil penilaian mereka menunjukkan persentase $76,67 \%$. Hal ini berarti buku ajar berada pada kualifikasi cukup dan perlu revisi secukupnya.

Seluruh kegiatan uji coba, mulai dari uji ahli (expert judgement) sampai uji kelompok kecil juga menghasilkan berbagai masukan melalui angket terbuka maupun wawancara langsung dengan subjek coba. Berdasarkan masukan-masukan yang diberikan, selanjutnya dilakukan revisi-revisi yang mengarah pada penyempurnaan produk buku ajar.

\section{SARAN}

Sebagai upaya untuk meningkatkan proses pembelajaran yang sesuai dengan karakteristik siswa khususnya siswa SD kelas IV pada bidang studi IPA, buku ajar model Dick And Carydapat digunakan sebagai alternatif yang Inovatif. Gambar-gambar yang berhubungan dengan lingkungan siswa sangat membantu dalam proses belajar mengajar di sekolah sehingga siswa dapat menyerap materi dengan baik.

\section{DAFTAR PUSTAKA}

Ali, M. 1992. Guru dalam Proses Belajar Mengajar. Bandung: Sinar Baru

Anglin, G. J. (Ed.). 1991. Instructional Technology: Past, Present, and Future. Colorado: Libraries Unlimited

Cennamo, K. S. \& Kalk, D. 2005. Systematic and systemic design of instructional as an iterative process: A functional model for practice in the real world. Educational Technology. 
Clark, R. E.1996. Media and learning. Dalam Plomp, T. \& Ely, D.P. (editor in chiefs). International Encyclopedia of Educational Technology. Oxford: Pergamon Press, halm. 59-63

Dick, W. \& Carey, L. 1990. The Systematic Design of Instruction. Illinois: Scott,Foresman and Company

Degeng, I N. S. 1997. Asumsi dan landasan teoretik desain pembelajaran. Jurnal Teknologi Pembelajaran: Teori dan Penelitian.

Gagne, R.M., Briggs, L.J. \& Wager, W.W. 1992. Principles of
Instructional Design. Orlando: Harcout Brace Jovanovich

Ibrahim, dkk. 2004. Media Pembelajaran. Malang: FIP Universitas Negeri Malang

Miarso, Y., dkk. 1984. Teknologi Komunikasi Pendidikan. Jakarta: Rajawali

Pannen, P. dan Purwanto. 2001. Penulisan Buku Ajar. Jakarta: Pusat Antar Universitas, Pusat Pengembangan Aktivitas Akademik Universitas Terbuka

Rohani, A. 1997. Media Instruksional Edukatif. Jakarta: Rineka Cipta 